\title{
PENGARUH FINANCING TO DEPOSIT RATIO (FDR), DANA PIHAK KETIGA (DPK) DAN RETURN ON ASSET (ROA) TERHADAP PEMBIAYAAN MUSYARAKAH
}

\author{
Djoko Sigit Gunanto, Suprihati, Firma Windi Aristi
}

\author{
Sekolah Tinggi Ilmu Ekonomi AAS Surakarta, Jawa Tengah \\ Email: djoko.sigitg@gmail.com
}

\begin{abstract}
Abstrak: Penelitian ini bertujuan untuk mengetahui pengaruh Financing To Deposit Ratio (FDR), Dana Pihak Ketiga (DPK) dan Return On Asset (ROA) terhadap pembiayaan musyarakah pada Bank Syariah Mandiri dari tahun 2010-2017 baik secara parsial maupun simultan. Penelitian ini menggunakan jenis data yang bersifat kuantitatif. Data yang digunakan menggunakan data sekuder yang diperoleh dari laporan keuangan triwulan. Metode yang digunakan penelitian ini adalah dengan menggunakan metode uji asumsi klasik dimana uji Asumsi Klasik ini terdiri dari empat uji yaitu uji Normalitas, uji Multikolinieritas, uji Heterokedastisitas dan uji Autokorelasi selain menggunakan uji Asumsi Klasik, dalam penelitian ini juga menggunakan uji dengan analisis data dari analisis regresi linier berganda serta menggunakan uji t atau uji parsial dan uji $F$ atau uji secara simultan maupun bersamasama. Populasi dalam penelitian ini adalah perbankan syariah yaitu Bank Syariah Mandiri tahun 2010-2017 sebanyak 32 diambil secara purposive sampling. Hasil penelitian menunjukkan bahwa variabel yang berpengaruh terhadap pembiayaan musyarakah adalah variabel Financing To Deposit Ratio (FDR) dengan nilai P-value sebesar 0,000 dimana nilai ini lebih besar dari 0,05 dan nilai $t_{\text {hitung }}$ sebesar -4,916 dimana nilai ini lebih besar dari nilai $t_{\text {tabel }}$ yaitu 2,0484 dan Dana Pihak Ketiga dengan nilai P-value sebesar 0,000 dimana nilai ini lebih besar dari 0,05 dan nilai $t_{\text {hitung }}$ sebesar 4,559 lebih besar dari nilai $t_{\text {tabel }}$ yaitu 2,0484 sedangkan variabel yang tidak berpengaruh terhadap pembiayaan musyarakah adalah variabel Return On Asset (ROA) dengan nilai P-value 0,428 dimana nilai ini lebih besar dari 0,05 dan $t_{\text {hitung }}$ lebih kecil dari $t_{\text {tabel }}$ dimana nilai thitung sebesar 0,805 dan nilai $t_{\text {tabel }}$ sebesar 2,0484. Secara simultan seluruh variabel yaitu FDR, DPK dan ROA secara bersama-sama berpengaruh terhadap pembiayaan musyarakah pada Bank Syariah Mandiri (BSM) tahun 2010-2017 dengan nilai signifikansinya sebesar 0,000 dimana nilai sig tersebut lebih kecil dari 0,05 sedangkan nilai $F_{\text {hitung }}$ lebih besar dari nilai $F_{\text {tabel }}$ dimana nilai $F_{\text {hitung }}$ sebesar 25,160 sedangkan nilai $F_{\text {tabel }}$ sebesar 2.95.
\end{abstract}

Kata kunci: Financing To Deposit Ratio (FDR), Dana Pihak Ketiga (DPK),

Return On Asset (ROA), musyarakah

\begin{abstract}
This study aims to determine the effect of Financing To Deposit Ratio (FDR), Third Party Funds (TPF) and Return on Assets (ROA) on musyarakah financing on Bank Syariah Mandiri from 2010-2017 both partially and simultaneously. This study uses quantitative data types. The data used uses secondary data obtained from quarterly financial reports. The method used in this study is to use the classic assumption test method where the Classic Assumption test consists of four tests namely Normality test, Multicollinearity test, Heterocedasticity test and Autocorrelation test in addition to using the Classical Assumption test, in this study also uses the test with data analysis from the analysis Multiple linear regression and using $t$ test or partial test and F test or test simultaneously or together. The population in this study is Islamic banking, namely Bank Syariah Mandiri in 2010-2017 as many as 32 taken by purposive sampling. The results showed that the variables that affect Musyarakah financing are variables Financing To
\end{abstract}


Deposit Ratio (FDR) with a P-value of 0,000 where this value is greater than 0.05 and the value of t count is -4.916 where this value is greater than the value of t table namely 2,0484 and Third Party Funds with a P-value of 0,000 where this value is greater than 0.05 and the value of $t$ count is 4,559 is greater than the ttable value of 2,0484 while the variable that has no effect on musyarakah financing is the Return on Asset variable (ROA) with a P-value of 0.428 where this value is greater than 0.05 and tcount is smaller than t table where the value of $t$ count is 0.805 and the value of $t$ table is 2.0484. Simultaneously all variables namely FDR, DPK and ROA jointly influence Musyarakah financing on Bank Syariah Mandiri (BSM) in 2010-2017 with a significance value of 0,000 where the sig value is smaller than 0.05 while the Fcount value is greater than Ftable value where Fcount value is 25,160 while Ftable value is 2,95.

Keywords: Financing To Deposit Ratio (FDR), Third Party Funds (DPK), Return on Assets (ROA), musyarakah

\section{PENDAHULUAN}

Perbankan syariah merupakan suatu badan ataupun lembaga keuangan yang prinsipprinsipnya menggunakan prinsip dengan berbasis syariah. Hal ini berbeda dengan perbankan konvensional yang hanya mengutamakan prinsip keuntungan saja. Perkembangan perbankan syariah mengalami perkembangan yang sangat pesat dibandingkan dengan perbankan konvensional. Banyak nasabah yang sudah menggunakan produk-produk perbankan syariah namun ada yang masih menggunakan perbankan konvensional.Pada produk perbankan syariah mempunyai tujuan yaitu untuk mengutamakan kesejahteraan masyarakat dan membantu taraf hidup perekonomian masyarakat. Produk yang ditawarkan kepada nasabah tidak hanya berupa mudharabah, musyarakah maupun murabahah saja tetapi terdapat produk lain seperti pinjaman qardh, wa'diah atau berupa titipan dan produk yang berupa ijarah, dari beberapa produk perbankan syariah juga terdapat kelemahan serta kelebihan dari masing-masing produk tersebut. Fakta yang terjadi pada pembiayaan antara mudharabah, musyarakah maupun murabahah yang paling mendominasi adalah pembiayaan murabahah atau jual beli selanjutnya diikuti dengan pembiayaan mudharabah dan pembiayaan musyarakah atau dengan bagi hasil hal ini mengakibatkan tidak optimalnya sistem bagi hasil (Annisa dan Dedi, 2017:300), sehingga tidak mencerminkan sistem prinsip perbankan syariah yaitu bagi hasil jika murabahah yang paling diunggulkan.

Fakta yang terjadi pada pembiayaan yang ditawarkan kepada nasabah kemudian nasabah tertarik akan produk pembiayaan dan melakukan pembiayaan tersebut tidak selalu berjalan lancar, terdapat faktor-faktor yang mempengaruhi pembiayaan baik pada perbankan maupun pada lembaga keuangan lainnya (Umiyati dan Leni, 2017:42). Faktor-faktor yang mempengaruhi pembiayaan pada bank syariah terbagi menjadi dua yaitu faktor internal dan faktor eksternal. Faktor internal merupakan salah satu faktor yang mempengaruhi pembiayaan yang disalurkan dimana terdapat rasio-rasio keuangan yang dapat menilai kondisi internal perusahaan antara lain FDR atau kepanjangan dari Financing To Deposit Ratio merupakan faktor internal yang mewakili dari rasio likuiditas, serta yang mewakili dari rasio profitabilitas pada bank syariah maupun bank konvensional adalah ROA atau Return on Asset, dari kedua faktor tersebut terdapat faktor internal lain yang mempengaruhi pembiayaan yaitu DPK atau Dana Pihak Ketiga dan NPF atau Non Performing Financing terkait dengan pembiayaan bermasalah (Umiyati dan Leni, 2017:43). Faktor kedua yaitu faktor ekternal yang dapat mempengaruhi pembiayaan pada bank syariah maupun lembaga keuangan lainnya adalah inflasi. Inflasi merupakan musuh terbesar bagi perekonomian, khususnya bagi bank syariah maupun bank konvensional. Pergerakan inflasi dari 
tahun ke tahun mengalami fluktuasi, hal ini dapat berpengaruh karena apabila inflasi tinggi akan berdampak pada nasabah yang ingin menabung karena nilai mata uang yang ditabung semakin rendah (Naufal dkk, 2017:392).

\section{KAJIAN TEORI}

\section{Pembiayaan}

Pembiayaan adalah suatu aktivitas pada bank syariah yaitu menyalurkan dana kepada pihak lain berdasarkan prinsip syariah. penyaluran dana didasarkan pada prinsip kepercayaan yang diberikan oleh pemilik dana kepada pengguna dana. Pihak pemilik dana percaya bahwa dana dalam bentuk pembiayaan yang diberikan pasti akan terbayar, begitu juga dengan pihak pengguna dana juga akan mendapatkan kepercayaan dari pemberi pembiayaan sehingga penerima pembiaayaan berkewajiban mengembalikan pembiayaan yang telah diterimanya (Ismail, 2011:105). Pembiayaan adalah pendanaan yang diberikan oleh satu pihak kepada pihak lain untuk mendukung investasi yang telah direncanakan baik dalam perencanaannya dilakukan sendiri maupun dilakukan oleh lembaga (Al-Arief, 2010:42).

Menurut Undang-Undang No 10 tahun 1998 tentang Perbankan, pembiayaan adalah penyediaan uang atau tagihan yang dapat di persamakan dengan itu, berdasarkan persetujuan atau kesepakatan antara bank dengan pihak lain yang mewajibkan pihak yang dibayarkan untuk mengembalikan uang atau tagihan tersebut setelah waktu tertentu dengan imbalan atau bagi hasil.

\section{Musyarakah}

Secara bahasa musyarakah berasal dari kata syirkah yang berarti adalah al-ikhtilath atau yang biasa dikenal dengan percampuran tidak hanya percampuran saja namun juga berkaitan dengan persekutuan, percampuran yang dimaksud adalah bercampurnya salah satu dari dua harta dengan harta lainnya tanpa adanya perbedaaan antara keduanya. Para fiqih mengartikan sebagi akad antara dua sekutu yang berkaitan dengan modal beserta keuntungannya (Waluyo, 2014:63). Musyarakah adalah suatu akad yang berlandaskan kerjasama antara dua pihak ataupun lebih dimana keduanya melakukan suatu usaha tertentu dengan sejumlah modal yang telah ditetapkan berdasarkan perjanjian dengan tujuan untuk bersama-sama menjalankan suatu usaha yang dilakukan bersama dan pembagian keuntungan ataupun kerugian dalam bagian yang ditentukan (Nawawi, 2012:151).

Pembiayaan musyarakah merupakan akad kerjasama antara dua orang atau lebih atau antara nasabah dengan bank syariah dimana masing-masing memberikan kontribusi untuk suatu usaha yang dijalankan, jika proyek usaha sudah dilakukan dan dijalankan serta mendapatkan keuntungan barulah bagi hasil ditentukan atau nisbahnya ditentukan antara bank syariah dengan nasabah dan harus sesuai dengan kontribusi modalnya (Antonio, 2001:94).

\section{Lembaga Keuangan}

Lembaga keuangan merupakan kata yang berasal dari bahasa inggris yaitu Financial Institution, dimana lembaga keuangan mempunyai arti yaitu suatu badan usaha yang kegiatannya yang bergerak dalam bidang jasa dalam menjalankan usahanya seperti melakukan funding 
maupun financing dengan tujuan untuk memenuhi kebutuhan masyarakat. Pengertian lain dari lembaga keuangan adalah suatu badan yang kegiatannya dalam bidang keuangan dengan melakukan penghimpunan maupun penyaluran dana kepada masyarakat (Mahbub, 2016:64). Secara umum lembaga keuangan berperan sebagai lembaga intermediasi.

Lembaga keuangan syariah adalah suatu lembaga yang kegiatannya berkaitan dengan keuangan baik berupa kegiatan penghimpun dana maupun kegiatan penyaluran dana (Soemitra, 2010:29). Menurut Sri Susilo, dkk. (2000:2-3) lembaga keuangan adalah suatu lembaga atau badan yang bergerak dalam bidang keuangan yang mencakup penghimpunan dan penyaluran dana atau dari nasabah untuk nasabah, serta berguna dalam membiayai investasi perusahaan.

\section{Bank Syariah}

Perbankan diatur dalam Undang-Undang No. 21 Tahun 2008 yang berbunyi bahwa perbankan syariah adalah segala sesuatu yang menyangkut tentang bank syariah dan Unit Usaha Syariah, mencakup kelembagaan, kegiatan usaha, serta tatacara dan proses dalam melaksanakan kegiatan usahanya. Bank dibagi menjadi dua yaitu bank syariah dan bank konvensional, bank syariah merupakan bank yang kegiatan usahanya sesuai dengan prinsip-prinsip syariah dan sistem keuntungannya dengan metode bagi hasil, margin maupun fee.

Bank syariah adalah bank bank yang yang beroperasi dengan tidak mengandalkan pada bunga, lembaga keuangan syariah atau bank syariah adalah suatu lembaga yang yang beroperasional serta produknya yang dikembangkan berlandaskan pada Al-Qur'an dan Hadist Nabi SAW (Muhammad, 2011:15). Bank syariah adalah bank dimana yang berasaskan pada kemitraan, keadilan, transparasi dan universal serta melakukan kegiatan usaha perbankan berdasakan prinsip syariah. kegiatan bank syariah melakukan implementasi dari prinsip ekonomi Islam dengan karakteristik seperti pelarangan riba, tidak mengenal konsep uang sebagai nilai waktu dari uang, konsep uang sebagai alat tukar bukan sebagai komoditas (Susyanti, 2016:45). Bank juga memiliki peran dan fungsi adapun fungsi bank dibagi menjadi dua yaitu fungsi umum dan fungsi khusus. Peran dan kedua fungsi tersebut sesuai dengan peraturan perundang-undang tentang perbankan syariah.

\section{Teori Financing To Deposit Ratio (FDR)}

Financing To Deposit Ratio (FDR) adalah rasio yang menggambarkan tingkat kemampuan bank syariah atau dalam pengertian lain adalah rasio dari jumlah kredit yang diberikan bank kepada nasabah dengan dana yang diterima bank dari nasabah dengan kata lain menyediakan dana dari kepada debitur dengan dana yang dikumpulkan oleh masyarakat (Dendawijaya, 2005:116). FDR adalah kemampuan bank khususnya bank syariah dalam mengembalikan dana kepada pihak ketiga melalui keuntungan yang didapat dari pembiayaan musyarakah (Ranchman, 2015:1506). FDR adalah perbandingan antara pembiayaan yang diberikan oleh bank dengan dana pihak ketiga yang berhasil dikerahkan oleh bank (Muhammad, 2005).

\section{Dana Pihak Ketiga (DPK)}

Dana pihak ketiga merupakan dana yang berasal dari masyarakat yang melakukan pembiayaan, maupun menabung, dengan berbagai produk simpanan yang dimiliki oleh bank. Pada dana pihak ketiga ini terdapat 2 metode yang diterapkan diperbankan syariah yaitu wa'diah (berupa simpanan) dan mudharabah (Kuncoro, 2002:155). Dana pihak ketiga merupakan hal 
yang penting bagi bank karena dana pihak ketiga dapat meningkatkan kualitas bank, jika tidak ada dana pihak ketiga bank juga tidak akan bisa melakukan penyaluran maupun penyimpanan dana. Dana pihak ketiga merupakan asset paling besar dan yang paling diandalkan oleh bank bisa mencapai $80 \%$ sampai $90 \%$, dana pihak ketiga merupakan salah satu sumber yang dapat digunakan untuk pembiayaan. Semakin besar bank berhasil menghimpuna dana dari pihak dana pihak ketiga maka semakin besar pula pembiayaan yang disalurkan oleh bank (Destiana, 2016:46).

\section{METODE PENELITIAN}

Penelitian ini menggunakan jenis data yang bersifat kuantitatif. Data yang digunakan menggunakan data sekuder yang diperoleh dari laporan keuangan triwulan. Metode yang digunakan penelitian ini adalah dengan menggunakan metode uji asumsi klasik dimana uji Asumsi Klasik ini terdiri dari empat uji yaitu uji Normalitas, uji Multikolinieritas, uji Heterokedastisitas dan uji Autokorelasi selain menggunakan uji Asumsi Klasik, dalam penelitian ini juga menggunakan uji dengan analisis data dari analisis regresi linier berganda serta menggunakan uji t atau uji parsial dan uji $\mathrm{F}$ atau uji secara simultan maupun bersama-sama. Populasi dalam penelitian ini adalah perbankan syariah yaitu Bank Syariah Mandiri tahun 20102017 sebanyak 32 diambil secara purposive sampling.

\section{HASIL DAN PEMBAHASAN}

\section{Statistik Deskriptif Analisis Variabel}

Statistik deskriptif merupakan gambaran deskriptif suatu data, dimana data yang dilihat dari nilai rata-rata (mean), maksimum, minimum dan standar deviasi sehingga tujuan menggunakan statistik deskriptif ini agar dapat dimengerti oleh pembaca (Ghozali, 2013). berikut hasil statistik deskriptif variabel.

Tabel 1. Statistik Deskriptif Descriptive Statistics

\begin{tabular}{|c|c|c|c|c|c|c|}
\hline & \multirow{N}{*}{} & Minimum & $\begin{array}{c}\text { Maximu } \\
\mathrm{m}\end{array}$ & \multicolumn{2}{|c|}{ Mean } & $\begin{array}{c}\text { Std. } \\
\text { Deviation }\end{array}$ \\
\cline { 2 - 7 } & $\begin{array}{c}\text { Statisti } \\
\mathrm{c}\end{array}$ & Statistic & Statistic & Statistic & Etr. & \\
& 32 & 77.66 & 95.61 & 85.7047 & .93375 & 5.28210 \\
FDR & 32 & 1163433 & 7657221 & 38760 & 2192604.6 \\
DPK & 32 & 2980742 & 4 & .03 & 1.413 & 99 \\
& 32 & .17 & 5.98 & 1.3463 & .19978 & 1.13015 \\
ROA & 32 & 1764021 & 4775387 & 10654 & 6026835.9 \\
MUSYA & 32 & 348509 & 3 & .16 & 04.134 & 02 \\
RAKAH & & & & & & \\
Valid N & 32 & & & & & \\
(listwise) & & & & & & \\
\hline
\end{tabular}

Sumber: data sekunder diolah dengan SPSS 23

Pada hasil di atas terdapat sampel sebayak 32 dari variabel Financing To Deposit Ratio (FDR), Dana Pihak Ketiga (DPK) dan Return On Asset (ROA) dimana pada FDR mempunyai nilai minimum sebesar 77.66 , nilai maksimum 95.61, nilai mean sebesar 85.7047 dengan nilai standar deviasi sebesar 5.28210. Pada DPK mempunyai nilai minimum 
sebesar 2.980.742, nilai maksimum sebesar 11.634 .334 serta nilai meannya sebesar 7657221.03 dengan nilai standarnya 2192604.699. Pada nilai minimum pada ROA sebesar 0.17, nilai maksimum sebesar 5.98 sedangkan mean sebesar 19978 sedangkan nilai standar deviasinya sebesar 1.13015. Pada musyarakah mempunyai nilai minimum sebesar 348.509, nilai maksimum sebesar 17.640.213 sedangkan pada mean sebesar 1065404.134 dan standar deviasinya sebesar 6026835.902

\section{Uji Asumsi Klasik}

a. Uji Normalitas

Tabel 2. Uji Normalitas

\begin{tabular}{|l|l|l|}
\hline Sign Hitung & Signifikansi & Keterangan \\
\hline 0,200 & 0,05 & $\begin{array}{c}1 . \text { Data berdistribusi } \\
\text { normal }\end{array}$ \\
\hline
\end{tabular}

Sumber: Data Sekunder yang diolah melalui SPSS 23, 2016

Berdasarkan tabel diatas nilai menunjukkan hasil normalitas pada nilai sign sebesar 0,200 sedangkan signifikansinya 0,05 . Hal ini uji normalitas berdistribusi normal karena nilai sign lebih besar dari nilai signifikansinya atau 0,200 > 0,05. Jadi secara keseluruhan dapat disimpulkan bahwa model regresi telah lolos uji normalitas.

b. Uji Multikolinieritas

Tabel 3. Uji Multikolinieritas

\begin{tabular}{|l|l|l|l|}
\hline Variabel & Tolerance & VIF & Keterangan terjadi \\
\hline $\begin{array}{l}\text { Financing To } \\
\text { Deposit Ratio } \\
\text { (FDR) }\end{array}$ & 0,754 & 1,327 & $\begin{array}{l}\text { Tidak terjadi } \\
\text { Multikolinieritas }\end{array}$ \\
\hline $\begin{array}{l}\text { Dana Pihak } \\
\text { Ketiga (DPK) }\end{array}$ & 0,836 & 1,197 & $\begin{array}{l}\text { Tidak } \\
\text { Multikolinieritas }\end{array}$ \\
\hline $\begin{array}{l}\text { Return On Asset } \\
\text { (ROA) }\end{array}$ & 0,872 & 1,147 & $\begin{array}{l}\text { Tidak terjadi } \\
\text { Mulitikolinieritas }\end{array}$ \\
\hline
\end{tabular}

Sumber: Data Sekunder yang diolah melalui SPSS 23, 2016

Berdasarkan tabel diatas uji mulitikolineritas syaratnya yang harus dipenuhi bahwa variabel independen harus terbebas dari multikolinieritas apabila nilai tolerance $>0,10$ dan VIF $<10,00$. Berdasarkan tabel diatas bahwa tidak terjadi multikolinieritas.

c. Uji Heterokedastisitas

Tabel 4. Uji Heterokedastisitas

\begin{tabular}{|l|l|l|}
\hline Variabel & Sig & Keterangan \\
\hline $\begin{array}{l}\text { Financing To Deposit } \\
\text { Ratio (FDR) }\end{array}$ & 0,949 & Tidak terjadi Heterokedastisitas \\
\hline $\begin{array}{l}\text { Dana Pihak Ketiga } \\
\text { (DPK) }\end{array}$ & 0,383 & Tidak terjadi Heterokedastisitas \\
\hline
\end{tabular}




\begin{tabular}{|l|l|l|}
\hline $\begin{array}{l}\text { Return On Asset } \\
\text { (ROA) }\end{array}$ & 0,077 & Tidak terjadi Heterokedastisitas \\
\hline
\end{tabular}

Sumber: Data Sekunder yang diolah melalui SPSS 23, 2016

Berdasarkan tabel diatas menunjukkan bahwa tidak terjadi heterokedastisitas sebab dilihat dari nilai signya setiap variabel sesuai dengan syarat yang dipenuhi yaitu lebih dari 0,05 .

d. Uji Autokorelasi

Tabel 5. Uji Autokorelasi

Model Summary ${ }^{\mathrm{a}, \mathrm{b}}$

\begin{tabular}{|l|r|r|r|l|l|}
\hline Model & \multicolumn{1}{|c|}{$\mathrm{R}$} & $\begin{array}{c}\mathrm{R} \\
\text { Square } \\
\mathrm{b}\end{array}$ & $\begin{array}{l}\text { Adjusted } \\
\text { R Square }\end{array}$ & $\begin{array}{l}\text { Std. Error of } \\
\text { the Estimate }\end{array}$ & $\begin{array}{l}\text { Durbin- } \\
\text { Watson }\end{array}$ \\
\hline 1 & $.940^{\mathrm{a}}$ & .884 & .872 & 1110143.0269 & 2.115 \\
\hline
\end{tabular}

Sumber: Data sekunder yang diolah melalui SPSS, 2016

Pada tabel 5 diatas bahwa autokorelasi dapat dilihat dari durbin-watson yang nilainya sebesar 2,115 berada diantara -2 dan 2, karena nilai dl sebesar 1.2437 dan nilai du sebesar 1.6505 Karena nilai Durbin-Watson sebesar 2,115 berada pada daerah du $\leq \mathrm{dw} \leq 4-\mathrm{du}$ $(1.6505 \leq 2,115 \leq 2,3495)$ maka dapat disimpulkan tidak terdapat autokorelasi.

e. Uji Regresi Linier Berganda

Tabel 6. Uji Regresi Linier Berganda

\section{Coefficients $^{\text {a }}$}

\begin{tabular}{|c|c|c|c|}
\hline \multirow{2}{*}{\multicolumn{2}{|c|}{ Model }} & \multicolumn{2}{|c|}{ Unstandardized Coefficients } \\
\hline & & B & Std. Error \\
\hline & $\begin{array}{l}\text { (Consta } \\
\mathrm{nt})\end{array}$ & 48282165.434 & 11917976.878 \\
\hline & FDR & -635141.239 & 129193.087 \\
\hline & DPK & 1.348 & .296 \\
\hline & ROA & 451703.980 & 561461.745 \\
\hline
\end{tabular}

Sumber: Data sekunder yang diolah melalui SPSS 23, 2016

Dari hasil output regresion dengan menggunakan alat bantu SPSS 23 sehingga dapat diperoleh persamaan regresi diatas adalah: $\mathrm{Y}=\mathrm{a}+\mathrm{b} 1 \mathrm{X} 1+\mathrm{b} 2 \mathrm{X} 2+\mathrm{b} 3 \mathrm{X} 3+\mathrm{e}$ 
Pembiayaan musyarakah $=48282165.434-635141.239$ FDR +1.348 DPK + 451703.980 ROA + e

\section{Pengujian Hipotesis}

a. Uji t

Tabel 7. Uji Statistik t

\begin{tabular}{|l|l|l|l|l|l|}
\hline Keterangan & $\mathbf{t}_{\text {hitung }}$ & $\mathbf{t}_{\text {tabel }}$ & Sig & Hipotesis & Keterangan \\
\hline $\begin{array}{l}\text { Financing To } \\
\text { Deposit Ratio (FDR) }\end{array}$ & $-4,916$ & 2,0484 & 0,000 & Terima H1 & Berpengaruh \\
\hline $\begin{array}{l}\text { Dana Pihak Ketiga } \\
\text { (DPK) }\end{array}$ & 4,559 & 2,0484 & 0,000 & Terima H2 & Berpengaruh \\
\hline $\begin{array}{l}\text { Return On Asset } \\
\text { (ROA) }\end{array}$ & 0,805 & 2,0484 & 0,428 & Tolak H3 & Tidak berpengaruh \\
\hline
\end{tabular}

Dari hasil uji t terlihat bahwa seluruh variabel yaitu FDR, DPK menunjukan pengaruh yang signifikan sedangkan pada variabel ROA menunjukkan tidak berpengaruh terhadap pembiayaan musyarakah. Dari tabel di atas maka hasil pengujian pengaruh parsial masing-masing variabel independen terhadap variabel dependen dapat dijabarkan sebagai berikut:

1) Hasil uji t terhadap variabel Financing To Deposit Ratio (FDR) memperoleh nilai signifikansi $=0,000<0,05$ atau $P$-value $<\alpha$ yaitu $0,000<0,05$ maka H0 ditolak dan H1 diterima, artinya variabel rasio Financing To Deposit Ratio (FDR) berpengaruh terhadap pembiayaan musyarakah pada laporan triwulan Bank Syariah Mandiri tahun 2010-2017. sedangkan variabel Financing To Deposit Ratio (FDR) nilai thitung sebesar 4,916 , dari hasil $t_{\text {hitung }}$ dengan $t_{\text {tabel }}$ bahwa $t_{\text {hitung }}$ lebih besar dari pada $t_{\text {tabel }}$ atau $-4,916>$ 2,0484 sehingga dapat diartikan bahwa variabel Financing To Deposit Ratio (FDR) secara statistik berpengaruh terhadap pembiayaan musyarakah Bank Syariah Mandiri periode 2010-2017. Hasil penelitian ini sesuai dengan penelitian Prasasti dan Prasetiono (2014) yang menyatakan bahwa Financing To Deposit Ratio (FDR) berpengaruh signifikan terhadap pembiayaan bagi hasil musyarakah pada Bank Umum Syariah di Indonesia dan hasil penelitian yang dilakukan oleh Asri dan Syaicu (2016) menyatakan bahwa secara parsial Financing To Deposit Ratio (FDR) terdapat pengaruh yang signifikansi terhadap pembiayaan bagi hasil pada perbankan syariah di Indonesia tahun 2010-2014.

2) Hasil uji t terhadap variabel Dana Pihak Ketiga (DPK) memperoleh nilai signifikansi = $0,000<0,05$ atau $P$-value $<\alpha$ yaitu $0,000<0,05$ maka $\mathrm{H} 0$ ditolak dan $\mathrm{H} 2$ diterima, artinya variabel Dana Pihak Ketiga (DPK) berpengaruh terhadap pembiayaan musyarakah laporan triwulan Bank Syariah Mandiri tahun 2010-2017. Hasil penelitian ini konsisiten dengan penelitian yang dilakukan oleh Liliani dan khairunnisa (2015) yang menyatakan bahwa secara parsial Dana Pihak Ketiga berpengaruh positif terhadap pembiayaan bagi hasil pada Bank Umum Syariah di Indonesia tahun 2010 dan 2013, kemudian penelitian yang dilakukan oleh Gumilarty dan Indriani (2016) menyatakan bahwa variabel Dana Pihak Ketiga berpengaruh positif terhadap pembiayaan bagi hasil pada Bank Umum Syariah periode 2010-2014 dan penelitian yang dilakukan oleh Fitriah (2014) menyatakan bahwa Dana Pihak Ketiga berpengaruh positif terhadap pembiayaan musyarakah pada Bank Umum Syariah di Indonesia dan penelitian oleh Destiana (2016) yang menyatakan bahwa Dana Pihak 
Ketiga berpengaruh positif terhadap pembiayaan musyarakah pada Bank Syariah di Indonesia

3) Hasil uji t terhadap variabel rasio Return On Asset (ROA) memperoleh nilai signifikansi $=0,428>0,05$ atau $P$-value $>\alpha$ yaitu $0,428>0,05$ maka $\mathrm{H0}$ diterima dan H3 ditolak, artinya variabel rasio Return On Asset (ROA) tidak berpengaruh terhadap pembiayaan musyarakah laporan triwulan Bank Syariah Mandiri tahun 2010-2017. Hasil penelitian ini sesuai dengan penelitian yang dilakukan oleh Liliani dan Khairunnisa (2015) yang menyatakan bahwa ROA tidak mememiliki pengaruh yang signifikan terhadap pembiayaan bagi hasil pada Bank Umum Syariah di Indonesia, dengan penelitian Annisa dan Fernanda (2017) dan Muniarti dan Firsta (2018) yang menyatakan bahwa ROA tidak memiliki pengaruh yang signifikan terhadap pembiayaan musyarakah namun penelitian ini bertentang dengan penelitian Gumilarty dan dan Indriani (2016) bahwa ROA memiliki pengaruh yang signifikan terhadap pembiayaan bagi hasil.

b. Uji F

Tabel 8. Uji statistik F

\begin{tabular}{|c|l|l|l|c|c|}
\hline Keterangan & $\mathbf{F}_{\text {hitung }}$ & $\mathbf{F}_{\text {tabel }}$ & signifikansi & Hipotesis & Hasil \\
\hline Variabel secara simultan & 25,160 & 2.95 & 0,000 & Terima H4 & berpengaruh \\
\hline
\end{tabular}

Sumber: Data sekunder yang diolah melalui SPSS 23, 2016

Dari uji $\mathrm{F}$ pada tabel 4.8 diatas didapat $\mathrm{F}_{\text {hitung }}$ sebesar 25,160 dengan probabilitas 0,000 $<0,05$. Jika membandingkan antara $F_{\text {hitung }}$ dengan $F_{\text {tabel }}$, bahwa nilai dari $F_{\text {hitung }}$ sebesar 25,160 dan $F_{\text {tabel }}$ sebesar 2.95 maka 25,160>2,95 dari hasil tersebut dapat disimpulkan bahwa variabel Financing To Deposit Ratio (FDR), Dana Pihak Ketiga (DPK) dan Return On Asset (ROA) bersama-sama berpengaruh terhadap pembiayaan musyarakah, sehingga pemilihan variabel Financing To Deposit Ratio (FDR), Dana Pihak Ketiga (DPK) dan Return On Asset (ROA) sebagai predictor pembiayaan musyarakah pada Bank Syariah Mandiri periode 2010-2017 sudah tepat.

c. Koefisien Determinasi

Tabel 9. Uji Koefisien Determinasi

Model Summary ${ }^{\text {b }}$

\begin{tabular}{|c|c|r|r|r|}
\hline Model & $\mathrm{R}$ & $\mathrm{R}$ Square & \multicolumn{1}{|c|}{$\begin{array}{c}\text { Adjusted R } \\
\text { Square }\end{array}$} & Std. Error of the Estimate \\
\hline 1 & $.854^{\mathrm{a}}$ & .729 & .700 & 3298702.321 \\
\hline
\end{tabular}

Sumber: Data sekunder yang diolah melalui SPSS 23, 2016

Berdasarkan tabel diatas diperoleh nilai $\left(a d j R^{2}\right)$ sebesar 0,700 atau sebesar 70,0\% hal ini menunjukkan bahwa persentase pengaruh variabel indenpenden terhapan variabel dependen sebesar 70,0\% sehingga variasi variabel indenpenden yang digunakan dalam model mampu menjelaskan sebesar $70,0 \%$ variasi variabel dependen sedangkan sisanya $30,0 \%$ dijelaskan oleh variabel lainnya. 


\section{KESIMPULAN}

Berdasarkan hasil analisis yang telah dilakukan maka dapat diambil kesimpulan sebagai berikut:

a. Hasil pengujian hipotesis pertama yang dilakukan dengan menggunakan uji t diperoleh nilai variabel Financing To Deposit Ratio (FDR) dilihat dari nilai $t_{\text {hitung }}$ sebesar -4,916 dan nilai $\mathrm{t}_{\text {tabel }}$ sebesar 2,0484 bahwa dari nilai tersebut $\mathrm{t}_{\text {hitung }}>\mathrm{t}_{\text {tabel }}$ sedangkan pada nilai $P$-value (sig) didapatkan sebesar $0,000<0,05$. Oleh karena itu, hipotesis kesatu dapat diterima sehingga variabel Financing To Deposit Ratio (FDR) berpengaruh terhadap pembiayaan musyarakah pada Bank Syariah Mandiri (BSM) dari tahun 2010-2017.

b. Hasil pengujian hipotesis kedua yang dilakukan dengan menggunakan uji t diperoleh nilai variabel Dana Pihak Ketiga (DPK) dilihat dari nilai $t_{\text {hitung }}$ untuk variabel DPK adalah 4,559 dan nilai $\mathrm{t}_{\text {tabel }}$ sebesar 2,0484 bahwa dari nilai tersebut $\mathrm{t}_{\text {hitung }}>\mathrm{t}_{\text {tabel }}$ sedangkan pada nilai $P$ value (sig) didapatkan sebesar $0,000<0,05$. Oleh karena itu, hipotesis kedua dapat diterima sehingga variabel Dana Pihak Ketiga (DPK) berpengaruh terhadap pembiayaan musyarakah pada Bank Syariah Mandiri (BSM) dari tahun 2010-2017.

c. Hasil pengujian hipotesis ketiga yang dilakukan dengan menggunakan uji t diperoleh nilai Return On Asset (ROA) dilihat dari nilai $t_{\text {hitung }}$ untuk variabel ROA adalah 0,805 nilai $t_{\text {tabel }}$ sebesar 2,0484 bahwa dari nilai tersebut $t_{\text {hitung }}<\mathrm{t}_{\text {tabel }}$ sedangkan pada nilai $P$-value (sig) didapatkan sebesar 0,428 >0,05. Oleh karena itu, hipotesis ketiga ditolak atau tidak diterima sehingga variabel Return On Asset (ROA) tidak berpengaruh terhadap pembiayaan musyarakah pada Bank Syariah Mandiri (BSM) dari tahun 2010-2017.

d. Hasil pengujian hipotesisi dengan menggunakan uji $\mathrm{F}$ dari varibael Financing To Deposit Ratio (FDR), Dana Pihak Ketiga (DPK) dan Return On Asset (ROA) secara bersama-sama berpengaruh terhadap pembiayaan musyarakah. hal ini variabel FDR, DPK, ROA sudah sesuai bahwa pembiayaan musyarakah dipengaruhi oleh ketiga faktor tersebut serta dibuktikan dengan hasil uji F dimana $P$-value sebesar 0,000 lebih kecil dari 0,05.

\section{DAFTAR PUSTAKA}

Al Arief, Nur Rianto. 2012. Lembaga Keuangan Syariah. Bandung: Pustaka Setia

Annisa,Suci \& Dedi Fernanda.2017. Pengaruh DPK.CAR, NPF, dan ROA terhadap pembiayaan Mudharabah dan Musyarakah pada Bank Syariah Mandiri periode 2011-2015. Jurnal Ekonomi dan Bisnis Dharma Andalas. Vol 19 No 2

Annisa,Suci \& Dedi Fernanda.2017. Pengaruh DPK.CAR, NPF, dan ROA terhadap pembiayaan Mudharabah dan Musyarakah pada Bank Syariah Mandiri periode 2011-2015. Jurnal Ekonomi dan Bisnis Dharma Andalas. Vol 19 No 2

Antonio, Moh Syafi’i.2001.Bank Syariah dari Teori ke Praktik. Jakarta:Gema Insani Press

Asri, Aida Sania dan Syaicu. 2016. Analisis Factor Yang Mempengaruhi Pembiayaan Berbasis Bagi Hasil Pada Perbankan Di Indonesia Periode 2010-2014. Diponegoro Journal of Management. Vol 5 no 3

Dendawijaya, Lukman. 2005. Manajemen Perbankan edisi 2. Bogor:Ghalia Indonesia

Destiana,Rina.2016.Analisis DPK dan risiko terhadap pembiayaan Mudharabah dan Musyarakah pada Bank Syariah Indonesia. Jurnal Logika. Vol XVII No 2 
Fitriah, Nurul Luluk. 2014. Pengaruh DPK, Modal Sendiri, Nisbah Bagi Hasil, LAR, dan CAR Terhadap pembiayaan Musyarakah pada Bank Umum Syariah di Indonesia. Artikel Ilmiah. STIE Perbanas Surabaya

Ghozali, Imam.2005. Aplikasi Analisis Multivariate dengan Program IBM SPSS. Semarang:Badan Penerbit Universitas Diponegoro

Ghozali, Imam.2011. Aplikasi Analisis Multivariate dengan Program IBM SPSS 19. Semarang: Badan Penerbit Universitas Diponegoro

Ghozali, Imam.2013. Aplikasi Analisis Multivariate dengan Program IBM SPSS 21. Badan Penerbit Universitas, Diponegoro: Semarang

Gumilarty, Gittrys Ratu Mashita dan Astiwi Indriani. 2016.Analisis Pengaruh DPK, NPF, ROA, Penempatan Dana Pada SBIS dan tingkat Bagi Hasil Terhadap Pembiayaan Bagi Hasil (Studi Pada Bank Umum Syariah di Indonesia Periode tahun 2010-2014). Diponegoro Journal Of Management. Vol 5 No 4

Institut Bankir Indonesia.2003.Bank Syariah: Konsep, Produk Dan Implementasi Operasional. Jakarta:Djambatan

Ismail. 2011. Perbankan Syariah. Jakarta:Kencana Prenada Media Group

Kasmir.2010.Analisis Laporan Keuangan. Jakarta:Raja Grafindo Persada

Kuncoro.2002.Manajemen Perbankan, Teori dan Aplikasi. Jakarta:PT Indeks Kelompok Gramedia

Mahbub, M. 2016. Pengaruh Pembiayaan Mudharabah Terhadap Pendapatan BMT UGT Sidogiri Capem Songgon Kabupaten Banyuwangi. Jurnal Hukum Islam. Vol 2 No 2

Muhammad.2005.Manajeman Bank Syariah. Yogyakarta: UPP AMP YKPN

Muniarti dan Firsta. 2018. Pengaruh DPK, NPF, CAR, ROA Terhadap Pembiayaan Mudharabahdan Musyarakah pada Bank Syariah Mandiri Periode 2011-2016. Jurnal Ekonomi dan Bisnis. Vol 20 No 1

Naufal, Tanesia, Sri Fadillah dan Helliana.2017.Pengaruh Dana Pihak Ketiga, Rasio Keuangan Bank, Inflasi dan Bi Rate Terhadap Volume Pembiayaan (Studi pada Bank Umum Syariah yang terdaftar di Bank Indonesia Periode 2012-2016. Prosiding Akuntansi, Vol 3 No 2

Nawawi, Ismail. 2012. Fikih Muamalah Klasik dan Kotemporer. Bogor: Ghadia Indonesia

Prasasti, Devki dan Prasetiono.2014.Analisis Pengaruh Financing To Deposit Ratio,Non Performing Financing, Spread Bagi Hasil dan tingkat Bagi Hasil Terhadap Pembiayaan Bagi Hasil (Studi pada Bank Umum Syariah di Indonesia Periode Tahun 2008-2013). Diponegoro Journal Of Management. Vol 4 No 4 
Djoko Sigit G, Suprihati, Firma Windi A. / Edunomika Vol. 02 No. 02 (Agustus, 2018)

Ranchman, Yoga Tantular.2015.Pengaruh Financing To Deposit Ratio (FDR), Non Performing Financing (NPF), Return On Asset (ROA), Capital

Ranchman, Yoga Tantular.2015.Pengaruh Financing To Deposit Ratio (FDR), Non Performing Financing (NPF), Return On Asset (ROA), Capital

Soemitra, Andri.2010. bank dan lembaga keuangan syariah. Jakarta: Kencana Prenada Media Group

Sri, Susilo, dkk. 2000. Bank dan lembaga keuangan lain. Jakarta: Salemba Empat

Subramanyam,Dkk.2013. Analisa Laporan Keuangan. Jakarta:Salemba Empat

Sugiyono.2010.metode penelitian bisnis (pendekatan kuantitatif, kualitatif, dan R\&D. Bandung: ALFABETA

Sugiyono.2017. Metode Penelitian Kuantitatif, Kualitatif, dan R\&D. Bandung: Alfabeta

Umiyati, dan Leni. 2017. Faktor yang Mempengaruhi Pembiayaan pada Bank Umum Syariah Devisa di Indonesia. Jurnal Ekonomi dan Perbankan Syariah. Vol 5 No 1

Waluyo.2014.Fiqih Muamalat. Yogyakarta: Gerbang Media Aksara

UU No 10 Tahun 1998 Tentang Pembiayaan 